\title{
Preliminary screening of the antibacterial activity of Cinnamonum zeylanicum (cinnamon) barks
}

\author{
Shahbaa M. Al-khazraji, \\ Ass .Prof, Foundation of Technical Education, Medical Technical Institute - Mansour. \\ Pharmacy Department.
}

\begin{abstract}
Cinnamon barks is used to treat microbial and fungal infections in folk medicine. To validate this use, the in- vitro antimicrobial activity of petroleum ether and alcoholic extract of cinnamon barks was evaluated against various microbial strains such as Staphylococcus aureus, Bacillus subtilis, Bacillus cereus, Salmonella typhimurium, Pseudomonas aeuriogenosa, Escherichia coli, Candida albicans and Saccharomyces cerevisiae by using disc diffusion method. Minimum inhibitory concentration (MIC) was determined by agar dilution technique. Both extracts showed significant inhibition against reference gram positive bacteria and fungal strains. MIC value of petroleum ether extract against gram positive and fungal strains was $300 \mu \mathrm{g} / \mathrm{ml}$ and that of alcoholic extract was $200 \mu \mathrm{g} / \mathrm{ml}$. Neither extract showed inhibitions against gram negative bacteria.
\end{abstract}

Keywords: Cinnamonum zeylanicum (cinnamon), Antimicrobial activity, Antifungal activity, Disc diffusion method, Agar dilution method

\section{Introduction}

The spread of drug resistant pathogens is one of the most serious threats to successful treatment of microbial diseases. Down the ages, essential oils and other ex-tracts of plants have evoked interest as sources of natural products. They have been screened for their potential uses as alternative remedies for the treatment of many infectious diseases [1]. World Health Organization (WHO) noted that majority of the world's population depends on traditional medicine for primary healthcare. Plant extracts have been used for many thousands of years [2] in food preservation, pharmaceuticals, alternative medicine and natural therapies [3, 4]. It is necessary to scientifically investigate those plants which have been used in traditional medicine to improve the quality of healthcare.

The development and spread of resistance to the existing antibiotics by microorganisms, calls for increased efforts in the development of new antibiotics. Although a number of plants with antimicrobial activities have been identified, great number still remains unidentified. The purpose of this work was therefore to evaluate antimicrobial activity of Cinnamonum zeylanicum barks cinnamon on different microbial strains.

Cinnamonum zeylanicum ( cinnamon ) is widely used in traditional system of medicine to treat diabetes $[5,6,7,8,9]$. Generally cinnamalehyde possesses hypoglycemic and hypolipidemic effect in streptosotocin -induced diabetic rats [ 5 ]. The usage of cinnamon in the treatment of infectious disease such as microbial and fungal infections [ 3 ] . Ethanol extract of cinnamonum zeylanicum revealed a significant scope to develop a novel broad spectrum of antibacterial herbal formulation and can be used for cooked food preservation [ 10 ]. Studies shows that Cinnamomum cassia can be very successfully be used against the food spoiling bacteria E. coli. Coliform bacteria are easily encountered in water hence C. cassia can also be employed for limiting the spread of these bacteria through water or reducing their concentration minimal damaging

limit. The minimum concentration required for $\mathrm{C}$. cassia to act upon these spoilage bacteria was found to be $0.0625 \% \mathrm{v} / \mathrm{v}$. Such a small concentration can be easily imparted in food products like apple juice (spoiled by E.coli), flavoured milk (spoiled by Pseudomonas aeruginosa) to inhibit the spoilage [ 11]. Studies revealed the inhibition zone for Klebsiella pneumonia was found to be $10 \mathrm{~mm}$ and for Candida albicans was $4 \mathrm{~mm}$. The solvent showed the zone of $3 \mathrm{~mm}$ on Klebsiella pneumonia and no inhibition on Candida albicans. And subsequently antimicrobial activity was positive for Klebsiella pneumonia and it was negligible effect on Candida albicans. And this antimicrobial effect was due to Cinnamaldehyde from Cinnamon species [ 12, 13 ] . To substantiate this claim, the present study was undertaken to evaluate the antimicrobial and antifungal potential of barks of Cinnamonum zeylanicum ( cinnamon ) by disc diffusion assay method.

\section{Materials And Methods}

Plant Material

Dried park of Cinnamonum zeylanicam obtained from commercial source and was identified at the National Herbarium of Iraq Botany Directorate in Abu-Ghraib . 


\section{Preparation of Extracts}

The barks of cinnamon was subjected to size reduction to get coarse powder. Extraction of $100 \mathrm{~g}$ of the coarse powder was performed by using soxhlet apparatus ( 40 cycles each), carried out first with petroleum ether $\left(60-80{ }^{\circ} \mathrm{C}\right)$ to defeat the material for overnight (yield: $1.49 \% \mathrm{w} / \mathrm{w}$ ) for overnight [14] . The defatted material was then extracted with alcohol to get alcoholic extract for overnight (yield: $8.15 \% \mathrm{w} / \mathrm{w}$ ). The extracts were concentrated for further studies at reduced pressure and temperature in a rotary evaporator . Test extracts were then dried crushed to fine powder and dissolved in $10 \%$ aqueous dimethylsulfoxide (DMSO) for the antibacterial studies .

\section{Chemicals}

Mueller Hinton agar and Sabourand dextrose agar; Ethanol; Petroleum ether (60-80) and Tween 80; standard Discs of Ciprofloxacin and Amphotericin B .

\section{Microbial Strains}

The test extracts were individually tested against a panel of microorganisms including Staphylococcus aureus ATCC 25923, Bacillus subtilis MTCC 441, Ba-cillus cereus MTCC 430, Pseudomonas aeruginosa MTCC 424, Salmonella typhimurium NCTC 74, Es-cherichia coli MTCC 443, Candida albicans MTCC 227, and Saccharomyces cerevisiae MTCC 170. These strains were obtained from Institute of Microbiological Technology, Chandigarh and National Chemical Laboratory Pune.. Bacterial strains were grown at $37 \square \mathrm{C}$ in Mueller Hinton agar (MHA) whereas fungal strains were at $30 \square \mathrm{C}$ in Sabouraud dextrose agar at $\mathrm{pH} 7.4$ for 48 hrs followed by frequent sub culturing to fresh me-dium and were used as test micro-organisms. The inoculums size of each test strain was $10^{8}$ bacteria/ml for disc diffusion assay, which was standardized by adjusting the optical density of the bacterial suspension to a turbidity corresponding to spectrophotometric absorbance $=0.08$ $\left(\mathrm{OD}_{620}=0.08\right)$ at $620 \mathrm{~nm} \quad$ [15].

\section{Disc Diffusion Method}

Screening of extracts for antibacterial activity was done by the disk diffusion method [15]. Bacterial inoculums were spread over the plates containing Mueller-Hinton agar using a sterile cotton swab in order to get a uniform microbial growth on both control and test plates. The extracts were dissolved in $10 \%$ aqueous dimethylsulfoxide (DMSO) with Tween $80(0.5 \% \mathrm{v} / \mathrm{v}$ for easy diffusion) and sterilized by filtration through a $0.45 \mu \mathrm{m}$ membrane filter. Under aseptic conditions, empty sterilized discs were impregnated with $100 \mu \mathrm{l}$ of each of the extracts of different concentration and left to dry under laminar flow cabinet overnight and then placed on the agar surface. Paper disc moistened with aqueous DMSO was placed on the seeded petriplate as a vehicle control. Standard discs containing ciprofloxacin $(0.8 \mu \mathrm{g} / \mathrm{ml})$ and amphotericin $(1.5 \mu \mathrm{g} / \mathrm{ml})$ were used as reference control. All petridishes were sealed with sterile laboratory parafilm to avoid eventual evaporation of the test samples. The plates were left for $30 \mathrm{~min}$ at room temperature to allow the diffusion of test drugs and kept for incubation.

\section{Incubation of Plates}

The plates containing the bacterial culture were incubated at $37^{\circ} \mathrm{C}$ for $18 \mathrm{~h}(18 \mathrm{~h}$ was fixed as the optimum time since there was no change in the inhibition up to $24 \mathrm{~h}$ ). On the other hand, the plates with fungal suspension were incubated at $25^{\circ} \mathrm{C}$ for $72 \mathrm{~h}$. After the incubation time, all the plates were examined for the presence of zones of inhibition with a caliper or the diameter as a property of antimicrobial activity. The antibacterial activity was interpreted from the size of the diameter of zone of inhibition measured to the nearest millimeter $(\mathrm{mm})$ as observed from the clear zones surrounding the discs.

\section{MIC Assay}

The agar dilution method recommended by the National Committee for Clinical Laboratory Standards [16] was used. A series of two fold micro dilution of each extract with $10 \%$ aqueous dimethylsulfoxide (DMSO) leading to a final concentration ranging from $1000 \mu \mathrm{g} / \mathrm{ml}$ to $100 \mu \mathrm{g} / \mathrm{ml}$ was prepared in Muellur Hinton agar at $48^{\circ} \mathrm{C}$. Plates were dried at room temperature for $30 \mathrm{~min}$ prior to spot inoculation with $3 \mu \mathrm{l}$ aliquots of culture containing approximately $10^{5}$ bacteria/ml of each organism. Inoculated plates were incubated at $37^{\circ} \mathrm{C}$ for $18 \mathrm{~h}$ and the MIC was determined. Experiments were carried out in triplicate. Inhibition of bacterial growth in the plates containing test extract was judged by comparison with growth in blank control plates. The MIC values were taken as the lowest concentration of the extracts in the wells of the micro titer plate that showed no turbidity after 24 hours of incubation at $37^{\circ} \mathrm{C}$. The turbidity of the wells in the micro titer plate was interpreted as visible growth of the microorganisms. 


\section{Results}

The petroleum ether and alcoholic extract of the of cinnamon barks were used in the present study to investigate their antimicrobial potential. Both gram-negative and gram positive bacteria and fungi were used as test organisms. Ciprofloxacin and amphotericin were used as positive controls.

The anti-bacterial activity of petroleum ether and alcoholic extract by disc diffusion method is summarized in Table 1 . The results revealed that, in disc diffusion assay, both extracts showed antibacterial activity with varying magnitudes against gram positive and fungal strains. The zone of inhibition above $6 \mathrm{~mm}$ in diameter was taken as positive result. No extract showed antimicrobial activity up to $10 \mathrm{mg} / \mathrm{ml}$ against gram negative strains except Pseudomonas aeruginosa. In comparison with petroleum ether extract, alcoholic extract showed slightly wider zone of inhibitions against all test microorganisms. In case of gram positive strains, both extracts showed good antimicrobial activity against Bacillus subtilis and Bacillus cereus than Staphylococcus aureus. Also Candida albicans is found to be more sensitive to both extracts than Saccharomyces cerevisiae. Activity of alcoholic extract was similar to that of conventional antibiotic amphotericin B in case of Saccharomyces cerevisiae. Ciprofloxacin and amphotericin showed prominent zone of inhibitions and MIC against test bacterial and fungal strains respectively.

MIC values of both extracts, by agar dilution method against all bacterial and fungal strains are also shown in Table 2 . No extract showed sensitivity against gram negative strains except Pseudomonas aeruginosa at $500 \mu \mathrm{g} / \mathrm{ml}$ for both extracts. MIC values of petroleum ether and alcoholic extracts against Candida albicans and Saccharomyces cerevisiae were $300 \mu \mathrm{g} / \mathrm{ml}$ and $200 \mu \mathrm{g} / \mathrm{ml}$ respectively. The lower MIC values of both the extracts against Bacillus subtilis and Bacillus cereus in comparison with Staphylococcus aureus showed their greater sensitivity towards the extracts of the cinnamon barks.

\section{Discussion}

Plants have provided a source of inspiration for novel drug compounds as plant-derived medicines have made significant contribution towards human health. Phytomedicines can be used for the treatment of diseases as is done in case of Unani and Ayurvedic system of medicines or it can be the base for the development of a medicine, a natural blueprint for the development of new drugs.

In the present study six different bacterial and two fungal strains were used to screen possible antimicrobial activity of cinnamon extracts. A result clearly indicates that both extracts of barks showed significant antimicrobial and antifungal activity.

We found that the extracts of the cinnamon inhibited the gram-positive bacteria better than the gramnegative. Generally, plant extracts are usually more active against gram positive bacteria than gram-negative bacteria [17]. The range of MIC values for all the test microorganisms correlated well with the results obtained using the disc diffusion method.

The MIC values for both extracts against Bacillus subtilis and Bacillus cereus are lower when compared with Staphylococcus aureus. This shows that these gram-positive bacterial strains are more susceptible to the effect of the extracts of barks of cinnamon with respect to its effect against Staphylococcus aureus.

Coumarins [18, 19, 20] and triterpenes [ 21,22,23] in plant extracts were found to be possess antimicrobial activity so it can be said that coumarins from petroleum ether extract and triterpenes from alcoholic extract may be responsible for proposed activity.

\section{Conclusion}

Both extracts of the plant produced good inhibition zones against the test organisms. So it is expected that they could be used to treat infections and diseases caused by these organisms and if the active ingredients of the extracts are isolated and possibly crystallized, therapeutic antibiotics could be produced from these compounds.

\section{References}

[1]. Tepe , B., Daferera, D., Sokmen ,M., Polissiou, M., Sokmen , A.,. In vitro antimicrobial and antioxidant activities of the essential oils and various extracts of Thymus eigii M. Zohary et P.H. Davis. J Agric Food Chem 2004; 52:1132-1137.

[2]. Jones FA. Herbs - useful plants. Their role in history and today. Euro J Gastroenterol Hepatol ,1996 ;8:1227-1231 .

[3]. Reynolds, J.E.F.. Martindale - the Extra Pharmacopoeia. 31st edition, London; Royal Pharmaceutical Society of Great Britain; 1996.

[4]. Lis-Balchin, M., Deans, S.G., Bioactivity of selected plant essential oils against Listeria monocytogenes. J Appl Bacteriol 1997; 82:759-762..

[5]. Subosh Babu ,P., Parbuseenivan ,S., and Ignaimuthu , S. : A potentialantidiabetic agent . Phytomedicine , 2007 Jan ;14(1): 15-22.

[6]. Khan, A.,and Safdor, M. Role of diet, Nutrients , Spices and Natural products in diabetes mellitus .Pakistan J.of Nutrition, 2003 ;2(17):1-12.

[7]. Jarvill- Tavilor , K.J.,Anderson , R.A., andGaves , D.J. m A hydroxychalone derived from Cinnamon function as a memicfor insulinin 3T3-L1adipocytes . J.Am Coll Netr ., 2001 Aug ;20(4): 327-36 .

[8]. Roffey , B., Atwal, A. , and Kubow , S . innamon water extracts increases glucose uptake, and inhibit adipoprotein secretion in 
3T3-L1 adipocytes . Med.Nutr. Food Res. , 2006 Aug;50(8) :739-45.s

[9]. Verspohl, E. L. , and Bauer, K. Anti-diabetic effect of Cinnamonum cassia and Cinnamonum zeylanicum in vitro and in vivo .Phsiotherapy Res. ,2005 ; 19(3): 203-206.

[10]. Usha , M., sherimali , R., Naquvi , S.M.A.. Antibacterial activity of acetone and ethanol extracts of Cinnamon and Ajowan on four food spoilage bacteria , I. Res. J. Biological Sci. ,2012.;1(4):7-11.

[11]. Nimji , P.D., Garg, H., Gupta, A., Srevastava, N., Katiyar, M., and Ramalingam ,C., Der Pharmacia Lettre, 2013,5 (1):53-59

[12]. Satya ,S., Parakash, S.D.V., Vangalabati, M., Research in Pharmacy ; $2012: 2(6): 32-35$.

[13]. Man Ring, S.I., Parhosib ,, A., Wibawa , S.K., J. of Applied and Industrial Biotechnology in Tropical Region ; 2008 : Vol. 1 .

[14]. Shailendra, S.,. Gurav, D., Gulkari, N.. J. D., and Arun, T. P. , Antimicrobial activity of Butea monosperma Lam. IJPT ,2008;7:23-24 .I

[15]. Andrews ,J.M., BSAC standardized disc susceptibility testing method . J Antimcrob Chemother , 2001 ;pp.48-57 .

[16]. NCCLS (National Committee for Clinical Laboratory Standards): Methods for dilution antimicrobial susceptibility tests of bacteria that grow aerobically. In Approved Standard M100-S12 Wayne. PA, NCCLS; 2002.

[17]. Lin, J., Opaku ,A.R., Geheeb-Keller, M., Hutchings, A.D., Terblanche, S.E., Jäger ,A.K., Preliminary screening of some traditional Zulu medicinal plants for anti-inflammatory and anti-microbial activi-ties. J Ethnopharmacol 1999; 68: $267-74$.

[18]. Hoult ,J.R.S., Paya,M. ,Pharmacological and biochemical actions of simple coumarins: natural products with therapeutic potential. Gen Pharmacol 1996; 27:713-722.

[19]. Soine, T.O. ,Naturally occurring coumarins and related physiological activities. J Pharm Sci 1964; 53:231-264

[20]. Scheel ,L.D. , The biological action of the coumarins. Microbiol Toxins 1972; 8:47-66.

[21]. Barre, J.T., Bowden, B.F., Coll, J.C., Jesus, J., Fuente ,V.E., Janairo. G.C., Ragasa, C.Y. ,A bioactive triterpene from Lantana camara. Phy-tochemistry 1997; 45: 321-324.

[22]. Scortichini , M., Pia Rossi, M. ,Preliminary in vitro evaluation of the antimicrobial activity of terpenes and terpenoids towards

[23]. Erwinia amylovora (Burrill) Winslow et al. J Appl Bacteriol 1991; 71:109-112.

[24]. Mendoza, L., Wilkens ,M., Urzua ,A., Antimicrobial study of the resinous exudates and of diterpenoids and flavonoids isolated from some Chilean Pseudognaphalium (Asteraceae). J Ethno-pharmacol 1997; 58: 85-88

Table-1:- The Zone if inhibition of the alcoholic extract and pet. Ether extract of cinnamon barks in different concentration

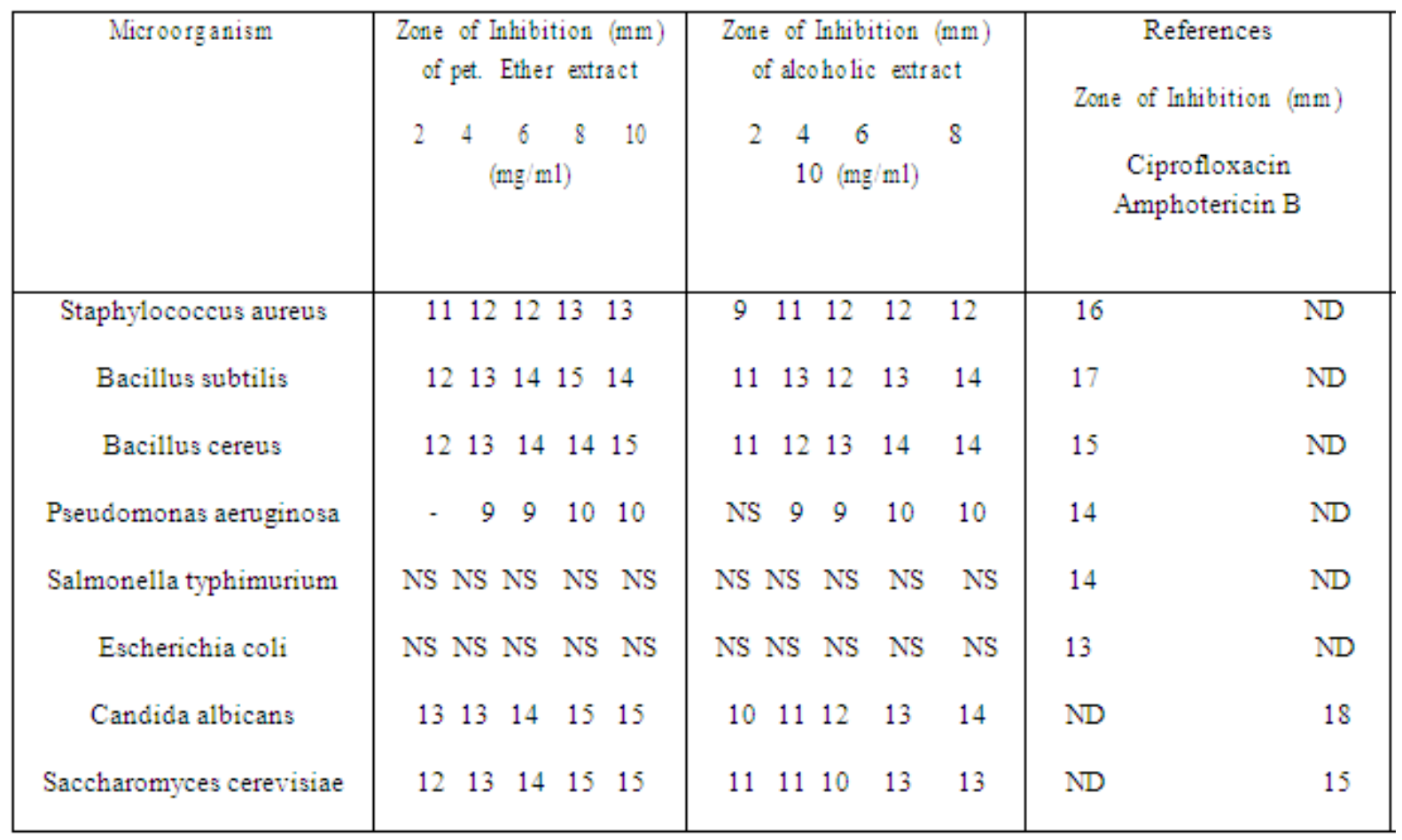

Values are means of three replications,

N.s. - Not sensitive at the concentration,

- = No zone of inhibition,

ND- Not determined. 
Preliminary screening of the antibacterial activity of Cinnamonum zeylanicum (cinnamon) barks

Table-2:- The Zone if inhibition of alcoholic and pet.ether extract of cinnamon barks in different concentration

\begin{tabular}{|c|c|c|c|c|}
\hline Microorganisms & $\begin{array}{l}\text { MIC of alcoholic } \\
\text { extract } \mu \mathrm{g} / \mathrm{ml}\end{array}$ & $\begin{array}{l}\text { MIC of pet.ether } \\
\text { extract } \mu \mathrm{g} / \mathrm{ml}\end{array}$ & \multicolumn{2}{|c|}{$\begin{array}{c}\text { References Ciprofloxacin } \\
\text { Amphotericin B }\end{array}$} \\
\hline Staphylococcus aureus & 300 & 400 & 0.5 & $\mathrm{ND}$ \\
\hline Bacillus subtilis & 200 & 300 & 2 & $\mathrm{ND}$ \\
\hline Bacillus cereus & 200 & 300 & 1 & $\mathrm{ND}$ \\
\hline Pseudomonas aeruginosa & 500 & 500 & 0.25 & $\mathrm{ND}$ \\
\hline Salmonella typhimurium & $\mathrm{Ns}$ & $\mathrm{Ns}$ & 0.5 & $\mathrm{ND}$ \\
\hline Escherichia coli & $\mathrm{Ns}$ & $\mathrm{Ns}$ & 0.05 & $\mathrm{ND}$ \\
\hline Candida albicans & 200 & 300 & $\mathrm{ND}$ & 1 \\
\hline Saccharomyces cerevisiae & 200 & 300 & $\mathrm{ND}$ & 1 \\
\hline
\end{tabular}

Values are means of three replications, n.s. - Not sensitive at the concentration, ND- Not determined. 